\title{
Salmonella Vaccine Vector System for Foot-and-Mouth Disease Virus and Evaluation of Its Efficacy with Virus-Like Particles
}

\author{
Yong Zhi ${ }^{1,2} \oplus$, Hyun Jung Ji ${ }^{1,3}$, Huichen Guo ${ }^{4}$, Jae Hyang Lim ${ }^{5,6}{ }^{\oplus}$, Eui-Baek Byun ${ }^{1}$, Woo Sik Kim ${ }^{7, *}$ and \\ Ho Seong Seo ${ }^{1,2, * \mathbb{D}}$
}

check for

updates

Citation: Zhi, Y.; Ji, H.J.; Guo, H.; Lim, J.H.; Byun, E.-B.; Kim, W.S.; Seo, H.S. Salmonella Vaccine Vector System for Foot-and-Mouth Disease Virus and Evaluation of Its Efficacy with Virus-Like Particles. Vaccines 2021, 9 , 22. https://doi.org/10.3390/ vaccines 9010022

Received: 15 December 2020 Accepted: 31 December 2020 Published: 5 January 2021

Publisher's Note: MDPI stays neutral with regard to jurisdictional clai$\mathrm{ms}$ in published maps and institutional affiliations.

Copyright: (C) 2021 by the authors. Licensee MDPI, Basel, Switzerland. This article is an open access article distributed under the terms and conditions of the Creative Commons Attribution (CC BY) license (https:// creativecommons.org/licenses/by/ $4.0 /)$.
1 Research Division for Radiation Science, Korea Atomic Energy Research Institute, Jeongeup 56212, Korea; yongzhi@kaeri.re.kr (Y.Z.); hyunjung@kaeri.re.kr (H.J.J.); ebbyun80@kaeri.re.kr (E.-B.B.)

2 Department of Radiation Science, University of Science and Technology, Daejeon 34113, Korea

3 Department of Oral Microbiology and Immunology, DRI, and BK21 Plus Program, School of Dentistry, Seoul National University, Seoul 08826, Korea

4 State Key Laboratory of Veterinary Etiological Biology, National Foot and Mouth Disease Reference Laboratory, Lanzhou Veterinary Research Institute, Chinese Academy of Agricultural Sciences, Lanzhou 730000, China; guohuichen@caas.cn

5 Department of Microbiology, Ewha Womans University College of Medicine, Seoul 07804, Korea; jlim19@ewha.ac.kr

6 Ewha Education \& Research Center for Infection, Ewha Womans University Medical Center, Seoul 07985, Korea

7 Functional Biomaterial Research Center, Korea Research Institute of Bioscience and Biotechnology, Jeongeup 56212, Korea

* Correspondence: kws6144@kribb.re.kr (W.S.K.); hoseongseo@kaeri.re.kr (H.S.S.)

\begin{abstract}
Foot-and-mouth disease virus (FMDV) causes a highly contagious and devastating disease in livestock animals and has a great potential to cause severe economic loss worldwide. The major antigen of FMDV capsid protein, VP1, contains the major B-cell epitope responsible for effectively eliciting protective humoral immunity. In this study, irradiated Salmonella Typhimurium (KST0666) were used as transgenic vectors containing stress-inducible plasmid pRECN-VP1 to deliver the VP1 protein from FMDV-type A/WH/CHA/09. Mice were orally inoculated with ATOMASalL3 harboring pRECN-VP1, and FMDV virus-like particles, where (VLP FMDV)-specific humoral, mucosal, and cellular immune responses were evaluated. Mice vaccinated with attenuated Salmonella (KST0666) expressing VP1 (named KST0669) showed high levels of VLP-specific IgA in feces and IgG in serum, with high FMDV neutralization titer. Moreover, KST0669-vaccinated mice showed increased population of IFN- $\gamma$ (type 1 T helper cells; Th1 cells)-, IL-5 (Th2 cells)-, and IL-17A (Th17 cells)-expressing $\mathrm{CD}^{+}$as well as activated $\mathrm{CD} 8^{+} \mathrm{T}$ cells (IFN- $\gamma^{+} \mathrm{CD} 8^{+}$cells), detected by stimulating

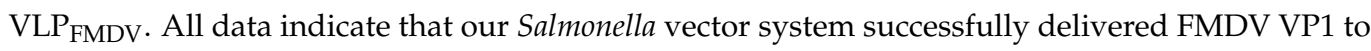
immune cells and that the humoral and cellular efficacy of the vaccine can be easily evaluated using VLP $_{\mathrm{FMDV}}$ in a Biosafety Level I (BSL1) laboratory.
\end{abstract}

Keywords: foot-and-mouth disease; VP1; live attenuated Salmonella vector; mucosal immunity; virus-like particle; radiation mutation

\section{Introduction}

Foot-and-mouth disease (FMD) may result in serious economic losses to the livestock industry by causing abortions, weight loss, and reduced milk production [1,2]. FMD virus (FMDV) is a highly contagious pathogen that causes blisters inside the mouth and bullous lesions on the feet of cloven-hoofed animals [2]. FMDV is a positive-sense, single-stranded RNA (ssRNA) virus that belongs to the genus Aphthovirus and the family Picornaviridae. In total, seven serotypes (A, O, C, Asia 1, and South African Territories 1, 2, and 3) of the virus have been identified, and multiple subtypes occur within each serotype [2-4]. 
FMDV virion consists of an icosahedral capsid with twelve pentamers of the four structural polypeptides (VP1 to VP4) enclosing about $8.3 \mathrm{~kb}$ long ssRNA genome [5].

Vaccination has so far been the best strategy to prevent and suppress the FMD epidemic [6]. The current FMD vaccines that are commonly used in endemic areas contain inactivated whole-virus with binary ethyleneimine (BEI) or formaldehyde, followed by formulating with an oil-based adjuvant $[7,8]$. Although the currently available vaccines have been shown to reduce FMDV prevalence in endemic areas, they have several limitations: (1) the requirement of a Biosafety Level III (BSL3) facilities for mass production of the virus antigen, (2) extensive genetic variation during manufacturing process, (3) short-term immunity due to lower immunogenicity, (4) lower cross-protective immunity against heterogenous serotypes and subtypes $[9,10]$. In addition, other important concerns regarding inactivated vaccines include multiple vaccination, cold chains, and accidental viral release from manufacturing facility [11].

Various studies have been conducted to develop the next generation FMDV vaccines. Live attenuated vaccines were generated through natural mutations by adapting FMDV in suckling mice in the United Kingdom, but large-scale clinical trial failed due to incomplete attenuation [12,13]. As the capsid proteins of FMDV have potent immunogenic properties, the empty capsid virus-like-particles (VLPs) produced in the Escherichia coli (E. coli) or Spodoptera frugiperda (Sf21) insect cell system have been developed as safer alternative

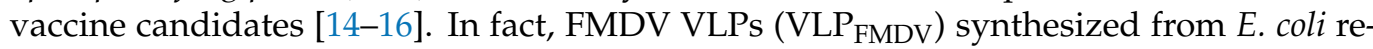
portedly generate similar levels of humoral and protective immune responses to those of current inactivated vaccines [17,18]. In general, recombinant conserved epitope of FMDV is another potential solution, owing to the availability of several highly cost-effective and safe protein expression systems $[19,20]$. As previous studies have confirmed the localization of multiple major antigenic sites in the G-H loop (amino acids 141-160) of the capsid protein VP1, VP1 or its short peptide has been extensively studied as a potent recombinant antigen [21-23]. Although these protein-based vaccines have several advantages, such as being economical and safe, their low cellular immune response has limited the commercialization of these vaccines.

An ideal vaccine to overcome the above limitations should be characterized by the ability to combine with immune modulation systems so as to activate pathogen-specific $\mathrm{T}$ cell immune responses [24,25]. Live replicating organisms are able to deliver immunogenic viral structural proteins by acting as natural adjuvants to stimulate the mucosal and cellular immune responses $[21,26,27]$. Human adenovirus type 5 vectors encoding the capsid protein precursor P1-2A of FMDV produced higher FMDV-specific IgG, CD4 ${ }^{+}$, and $\mathrm{CD}^{+} \mathrm{T}$ cell responses than inactivated FMDV vaccine in immunized mice [28]. Salmonella, as an antigen transfer vector, is one of the most widely studied bacteria because it can invade the gut-associated lymphoid tissue and effectively generate mucosal and cellular immune responses [29,30]. For example, Salmonella Typhimurium strain X9558 delivers pneumococcal surface PspA protein to mucosal immune cells, thereby providing protection against pneumococcal challenge in mice [31,32].

Salmonella is a Gram-negative zoonotic bacteria that is a leading cause of food-borne diseases in developed countries and causes bloodstream infections in infants and elderly in developing countries [33]. Salmonella are frequently asymptomatic in livestock, but has been highly associated with mild and severe diarrhea in piglets [34,35]. In pigs, Salmonella Typhimurium is by far the most isolated serotype in the EU and US, followed by Salmonella Derby and Salmonella Arizona. It is useful for heterologous antigens or drug delivery vectors to protect intracellular pathogens, including viruses, due to their ability to induce both humoral and cellular immune responses in both mucosal and systemic compartments [36,37].

We previously developed an effective bacterial attenuation method using radiation mutation technology (RMT) that can easily reduce the virulence of pathogenic bacteria without genetic manipulation [38]. In the present study, we created a non-toxic Salmonella Typhimurium strain, named KST0666, from a clinical isolate (ST454 strain) using RMT and 
developed an effective FMDV VP1 protein stress-inducible expression system that delivers antigen to mucosal immune cells. Moreover, we evaluated the ability of this new antigen delivery vector system to elicit effective mucosal, humoral, and cellular immune responses.

\section{Materials and Methods}

\subsection{Ethics Statement}

The present study was performed in strict accordance with the recommendations in the guide for the care and use of Laboratory Animals of the National Institutes of Health. All animal experiments were ethically approved by the committee on the use and care of animals at the Korea Atomic Energy Research Institute (KAERI; approval No. IACUC2018-007) and performed according to accepted veterinary standards set by the KAERI animal care center. To euthanize the mice, a $\mathrm{CO}_{2}$ inhalation method as specified by KAERI Institutional Animal Care and Use Committee guidelines was used.

\subsection{Reagents}

All chemical reagents used in the present study were purchased from Sigma-Aldrich (St. Louis, MO, USA).

\subsection{Bacteria and Plasmid}

Bacteria and plasmids used in the present study are listed in Table 1. Salmonella or E. coli were grown in Luria Broth (LB; Becton Dickson, Franklin Lakes, NJ, USA) in a rotary shaker at $200 \mathrm{rpm}, 37^{\circ} \mathrm{C}$. The media were supplemented with kanamycin $(50 \mu \mathrm{g} / \mathrm{mL})$, chloramphenicol $(15 \mu \mathrm{g} / \mathrm{mL})$ or ampicillin $(100 \mu \mathrm{g} / \mathrm{mL})$ if required. The KST0666 strain was selected from Salmonella Typhimurium strain ST454 using RMT. Briefly, the wildtype (WT) strain was cultured in LB (OD = 0.5) and subjected to irradiation (1.2 kGy) using Co-60 gamma irradiator (point source AECL, IR-221, MDS Nordion International Co., Ltd., Ottawa, ON, Canada) for $1 \mathrm{~h}$. Irradiated ST454 WT was spread on LB agar followed by incubation for $48 \mathrm{~h}$ at $37^{\circ} \mathrm{C}$. Then, 20 colonies were randomly selected for in vitro invasion assay. The isolate showing the lowest invasion ability was named KST0666.

Table 1. Plasmids and strains used in this study.

\begin{tabular}{cccc}
\hline Types & Name & Characteristics & Origin \\
\hline Plasmids & pET28a(+) & Expression vector, Kan ${ }^{\mathrm{R}}$ & Novagene \\
& pRECN & derived from pET28a(+), with strong expression of promoter recN & {$[38]$} \\
& from . coli & in this study \\
\hline Strains & KST0666 & derived from pRECN with VP1 gene & in this study \\
& KST0667 & attenuated Salmonella & in this study \\
& KST0668 & KST0666 harboring pET28a(+) & in this study \\
& KST0669 & KST0666 harboring pRECN & in this study \\
& LT2 & KST0666 harboring pRECN-VP1 & [39] \\
& ST454 & Salmonella Typhimurium & in this study \\
\hline
\end{tabular}

VP1-expressing plasmid was constructed as described previously [38]. Briefly, codon optimized VP1 DNA of FMDV-type A/WH/CHA/09 (accession no. JF792355) was synthesized by Cosmo Genetech Inc. (Seoul, Republic of Korea) and cloned into pRECN plasmid. The resulting plasmid named pRECN-VP1 (KST0669) was transferred into KST0666 by electroporation $(1.8 \mathrm{kV}, 25 \mu \mathrm{F}$, and $200 \Omega)$.

\subsection{High-Throughput Sequencing Using an Illumina Platform}

To investigate nucleotide substitutions, deletions, and insertions in the attenuated strain KST0666, its genome was sequenced using Illumina HiSeq 2000 (150 bp paired-end) with 825.98-fold coverage. The total length of read bases was 6,522,648,074 bp, which covered $98.09 \%$ length of the WT ST454 strain. The raw reads from the ST454 genome were mapped and aligned to the reference genome sequence using Burrows-Wheeler aligner (BWA-0.7.12) and Picard. Next, the genetic variants were detected using SAMTools (ver. 1.2). 


\subsection{Cell Invasion Assay}

The porcine intestinal epithelial cell line IPEC-J2 was cultured in 48-well cell culture plates (SPL, Pocheon, Korea). When the cells reached about $90 \%$ confluence, the randomly selected irradiated Salmonella ST454 isolates $(n=20)$ were added to the cells at a multiplicity of infection (MOI) of 10 and incubated for $30 \mathrm{~min}$ at $37^{\circ} \mathrm{C}$. The cell monolayer was washed three times with phosphate-buffered saline (PBS) followed by cell lysis using $0.05 \%$ trypsin EDTA and $0.25 \%$ Triton X-100. Finally, the cell lysate was serially diluted with PBS, and the diluents were plated onto an LB agar plate to count the bacterial colonies. The invasion rate was calculated as [recovered colony-forming units (CFU)/original CFU] $\times 100 \%$.

\subsection{VLP $F M D V$ Purification}

$\mathrm{VLP}_{\mathrm{FMDV}}$ were purified using three SUMO fusion proteins in the same E. coli system containing pSMKVP0, pSMAVP1, and pSMCVP3 established at Lanzhou Veterinary Research Institute (LVRI; Lanzhou, China). The expression, purification, and proteolytic cleavage of fusion proteins were performed as described previously [14]. The assembled VLP $_{\text {FMDV }}$ were identified using a Zetasizer-Nao instrument (DLS, Malvern Zetasizer-Nano ZS90; Worcestershire, UK) and transmission electron microscopy (Nikon, Tokyo, Japan).

\subsection{Western Blot Analysis}

Bacterial strains KST0666, KST0667, KST0668, and KST0669 were grown in LB and harvested at $\mathrm{OD}_{600}=0.6-0.8$, followed by separation of the supernatant and pellet. The pellets were lysed using $1 \% v / v$ Triton X100 and $0.1 \% w / v$ SDS in PBS, and the lysates were loaded and separated on 12\% Bis-Tris BOLT gels (Invitrogen, San Diego, CA, USA), followed by transfer onto nitrocellulose membranes. The membranes were blocked with $5 \%$ skimmed milk in tris-buffered saline (TBS) for $60 \mathrm{~min}$ at room temperature. They were then incubated with rabbit anti-FMDV IgG (1:1000; LVRI) or rabbit polyclonal anti-DnaK IgG (1:3000; Abcam, Cambridge, UK) followed by incubation with an anti-rabbit IgG conjugated with horseradish peroxidase (HRP; 1:5000; Sigma-Aldrich) for $1 \mathrm{~h}$ at room temperature. The protein bands were visualized using Enhanced Chemiluminescent Western Blotting Substrate (Thermo Scientific, Waltham, MA, USA). Bio-Rad ChemiDoc ${ }^{\mathrm{TM}}$ Touch imaging system (Bio-Rad Laboratories, Hercules, CA, USA) and Bio-Rad CFX Manager software 3.1 (Bio-Rad Laboratories) were used for data acquisition and analysis.

\subsection{Reverse Transcription-Quantitative PCR (RT-qPCR) Analysis}

The mouse macrophage RAW264.7 cell line (Korea Cell Line Bank, Seoul, Republic of Korea) was cultured in six-well culture plates (SPL) with Dulbecco's modified Eagle's medium (DMEM; GIBCO, Carlsbad, CA, USA) without antibiotics and infected at an MOI of 10 with KST0666, KST0667, KST0668, or KST0669. After 2 and 18 h post-infection, the expression of VP1 was quantified by RT-PCR. The primers used are listed in Table 2. Total RNA isolation and cDNA synthesis was performed using an RNeasy ${ }^{\circledR}$ mini kit (Qiagen, Hilden, Germany) and Primescript 1st strand cDNA synthesis kit (Takara Bio, Otsu, Japan), respectively. RT-PCR amplification and analysis were achieved using Bio-Rad CFX Connect ${ }^{\mathrm{TM}}$ Real-Time System (Bio-Rad Laboratories) with SYBR Green Master Mix (Takara Bio). The relative gene expression was quantified using the $2^{-\Delta \Delta \mathrm{Ct}}$ method [40]. The 16S rRNA $r r s H$ was selected as a control to normalize the expression levels. 
Table 2. Primers used in this study.

\begin{tabular}{cr}
\hline Primers & Sequence $\left(\mathbf{5}^{\prime} \mathbf{-} \mathbf{3}^{\prime} \mathbf{)}\right.$ \\
\hline recN-F & AAC CAT GGT TAA TAT CCG CAA TAC AC \\
recN-R & TTG AAT TCT GTG CAT TCC TCT CCC \\
VP1 amplification-F & AAG AAT TCA CTA CTT CGA CGG GGG AAA GCG \\
VP1 amplification-R & GGC GGT TAA ACA GAG CTT AAC AAG TGA GCG GCC GCA A \\
VP1 diagnosis-F & CCG GTT ACT GCG ACA CTA GT \\
VP1 diagnosis-R & TTT AAC CGG CGC CAC AAT TT \\
VP1-RT-PCR-F1 & GAT CCG GTT ACT GCG ACT GT \\
VP1-RT-PCR-R1 & ACA ATA GGT TTC CGC CCG TT \\
\hline
\end{tabular}

\subsection{Fluorescence Microscopic Analysis}

RAW264.7 cells were plated on imaging slides ( $\mu$-Slide 12-well, glass bottom, Ibidi $\mathrm{GmbH}$, Munich, Germany), followed by infection with KST0669 at an MOI of 10. Unbound bacteria were washed out with PBS followed by fixation with $2 \%$ paraformaldehyde at $4{ }^{\circ} \mathrm{C}$ for $20 \mathrm{~min}$ and permeabilization with $0.1 \%$ Triton-X100 for $20 \mathrm{~min}$. The cells were then washed three times with PBS and blocked with $3 \%$ bovine serum albumin (BSA; SigmaAldrich) in PBS for up to $2 \mathrm{~h}$ at room temperature. The cells were then incubated with rabbit anti-FMDV IgG, followed by staining with FITC-conjugated goat anti-rabbit IgG (Sigma-Aldrich). The nuclei were stained with $150 \mathrm{ng} / \mathrm{mL}$ 4',6-diamino-2-phenylindole (DAPI; Thermo Scientific). The slides were washed with PBS and mounted with mounting medium (Dako, Carpinteria, CA, USA). All images were captured using an Olympus CX41 fluorescence microscope (Olympus Corporation, Tokyo, Japan).

\subsection{Mice Experiments}

All mice were obtained from OrientBio Inc. (Suwon, Republic of Korea). For comparison of $50 \%$ lethal dose (LD50), 6 -week-old BALB/c mice ( $n=4$ per group) were injected intraperitoneally with different CFUs (ranging from $1 \times 10^{4}$ to $3 \times 10^{8} \mathrm{CFU} / 200 \mu \mathrm{L}$ ) of Salmonella strain ST454 WT or KST0666. The survival of infected mice was monitored for 14 days. To assess the ability of KST0669 to induce immune responses, 6-week-old BALB/c mice ( $n=5$ per group) were randomly assigned five mice per individually ventilated housing cages (Orient Bio, Sungnam, Korea) maintained in an animal BSL2 facility at $22-23{ }^{\circ} \mathrm{C}$ on a 12:12 light:dark cycle. Mice were administered orally with $100 \mu \mathrm{L}$ of $10 \%$ sodium bicarbonate for $4 \mathrm{~h}$ prior to inoculate orally with either KST0668 or KST0669 $\left(10^{8} \mathrm{CFU} / 100 \mu \mathrm{L}\right)$ at 2-week intervals. Feces and blood samples were collected every week for analysis. Blood was obtained from the submaxillary sinus of the mice. Additionally, to verify the safety of KST0669 in mice, the spleen, liver, and mesenteric lymph node from KST0669-vaccinated mice were isolated on day 1, 2, 3, 5, and 7 post-inoculation, and the number of viable bacteria in each organ were determined by plating serially diluted homogenates or blood on LB agar plates. Bacterial counts were determined by enumeration of CFU. To further confirm the protective capacity of KST0669 vaccination, 6-week-old BALB/c mice ( $n=5$ per group) were orally vaccinated twice with $\mathrm{KST} 0669\left(10^{8} \mathrm{CFU}\right)$ at 2-week intervals. On day 14 , after the last vaccination, the mice were orally challenged with $10^{6} \mathrm{CFU}$ of Salmonella Typhimurium LT2 and bacterial loads in the caecum, spleen, and blood were counted after serial dilution on LB agar plates on day 2, 4, and 6 post-infection. In the vaccinated group, mice mortality was observed and recorded for 2 weeks after the challenge.

\subsection{Measurement of Mice Immunoglobulin}

Feces and blood were collected from vaccinated mice ( $n=5$ per group) on day 0,7 , 14,21 , and 28 since the first vaccination as described above. Antibody titers in blood and feces were measured by enzyme-linked immunosorbent assay (ELISA). Briefly, 96-well

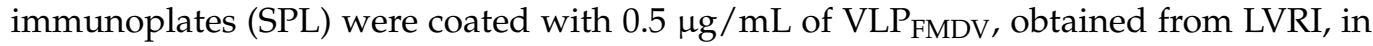
carbonate buffer $(\mathrm{pH}=9.6)$ overnight at $4{ }^{\circ} \mathrm{C}$. After blocking the plates with $2 \%$ BSA at room temperature for $45 \mathrm{~min}$, they were washed with PBST (PBS containing 0.05\% 
Tween-20) and then incubated with $100 \mu \mathrm{L}$ of diluted mouse serum or fecal fluid at room temperature for $1 \mathrm{~h}$. After washing the plates with PBST, HRP-conjugated goat anti-mice $\operatorname{IgA}$, IgG, or IgM (1:3000; Sigma-Aldrich) were added to the wells and incubated for $30 \mathrm{~min}$ at room temperature. The plates were then washed with PBST, and $100 \mu \mathrm{L}$ of 3,3',5,5'-tetramethylbenzidine substrate reagent (BD Biosciences, San Diego, CA, USA) was added. After color development, $50 \mu \mathrm{L}$ of $2 \mathrm{~N} \mathrm{H}_{2} \mathrm{SO}_{4}$ was added and the absorbance was measured at $450 \mathrm{~nm}$ using Bioteck Eponch Microplate Spectrophotometer (Biotek, Winooski, VT, USA).

\subsection{Virus Neutralization Assays}

FMDV neutralizing antibody titers of serum obtained from vaccinated mice were measured as described previously [41]. Briefly, isolated mouse serum was inactivated at $55^{\circ} \mathrm{C}$ for $1 \mathrm{~h}$ and $50 \mu \mathrm{L}$ serum was serially diluted in DMEM in a 96-well plate. Then, $50 \mu \mathrm{L}$ of FMDV suspension (tissue culture infective dose $=100$ ) was mixed with the serum and incubated for another $1 \mathrm{~h}$ at $37^{\circ} \mathrm{C}$. Subsequently, $50 \mu \mathrm{L}$ of BHK-21 cell suspension $\left(2 \times 10^{4}\right.$ cells) was added and incubated at $37^{\circ} \mathrm{C}$ for $72 \mathrm{~h}$ and the cytopathic effects of each well were investigated. The virus neutralization titers of serum were calculated by the Spearman-Karber method [42].

\subsection{Flow Cytometry}

Then, 2 weeks after the last immunization, the spleen homogenates of immunized mice were filtrated through a cell strainer ( $40 \mu \mathrm{m}$; BD Biosciences) in RPMI 1640 medium (GIBCO) containing 10\% fetal bovine serum (GIBCO) and then red blood cells (RBCs) were lysed with RBC lysis buffer (Sigma-Aldrich) for $3 \mathrm{~min}$ at room temperature. Single-cell suspension $\left(2 \times 10^{6}\right.$ cells) was incubated with $10 \mu \mathrm{g} / \mathrm{mL} \mathrm{VLP} \mathrm{FMDV}_{1}, 2 \mu \mathrm{g} / \mathrm{mL}$ anti-CD28 monoclonal antibody (clone 37.51; eBioscience, San Diego, CA, USA), $0.5 \mu \mathrm{g} / \mathrm{mL}$ GolgiStop (eBioscience), and $0.5 \mu \mathrm{g} / \mathrm{mL}$ GolgiPlug (BD Biosciences) for $12 \mathrm{~h}$ at $37^{\circ} \mathrm{C}$. Next, the cells were washed with cold PBS and stained with live/dead staining kit (In Vivo Gen, San Diego, CA, USA), anti-CD4-BV450 (clone RM4-5; BD Biosciences), anti-CD8 $\alpha$-FITC antibodies (clone 53-6.7; BD Biosciences), anti-CD3e-APC-Cy7 (clone UCHT1; eBioscience) at $4{ }^{\circ} \mathrm{C}$ for $30 \mathrm{~min}$. The cells were fixed using Cytofix/Cytoperm Plus Kit (BD Biosciences), washed, and then stained intracellularly with anti-mouse IFN- $\gamma$-PE (anti-mIFN- $\gamma$-PE; clone XMG1.2; BD Bioscience), anti-mIL-5-APC (clone TRFK5; BD Bioscience), and anti-mIL-17APE-Cy7 (clone eBio17B7; eBioscience) at $4{ }^{\circ} \mathrm{C}$ for $30 \mathrm{~min}$. The stained cells were analyzed with MACSQuant VYB flow cytometer (Milteny Biotech, San Diego, CA, USA) and the results were analyzed with FlowJo software (TreeStar, Ashland, OR, USA).

\subsection{Cytokine ELISA}

For analysis of cytokine production, the culture supernatants of splenocytes prepared as described above were collected, and cytokine levels (IFN- $\gamma$, IL-5, and IL-17A) were measured with ELISA kit according to the manufacturer's instruction (BD Bioscience).

\subsection{Statistical Analysis}

All data were presented as mean \pm SEM of three independent experiments performed in triplicate. Results were analyzed by Student's $t$ test using the GraphPad Prism 6 software (San Diego, CA, USA). Comparisons among groups were also analyzed by two-way ANOVA followed by a post-hoc Tukey test. $p$ values $<0.05,<0.01$, and $<0.001$ were considered statistically significant.

\section{Results}

\subsection{Development of Attenuated Salmonella Strain Using RMT}

An attenuated Salmonella strain was developed using previously reported method [38]. After induction of mutations using $\gamma$-radiation in the WT strain (ST454), the isolates showing significantly reduced replication capacity in the porcine IPEC-J2 cells were selected 
as the attenuated candidate strains. Interestingly, most of the selected strains exhibited lower replication abilities than the parent strain (ST454), and among them, \#03 colony showed the lowest replication rate compared to the other mutated isolates (Figure 1A). This lowest-replicating mutant strain without vector was selected for subsequent studies and named KST0666. In addition, the abbreviations of strains used in all in vitro and in vivo experiments were named as follows: attenuated Salmonella strain (KST0666) transformed with the vectors (pET28a or pRECN) lacking the insert was named as KST0667 and KST0668, respectively. KST0666 strain harboring pRECN-VP1 was named as KST0669.

A

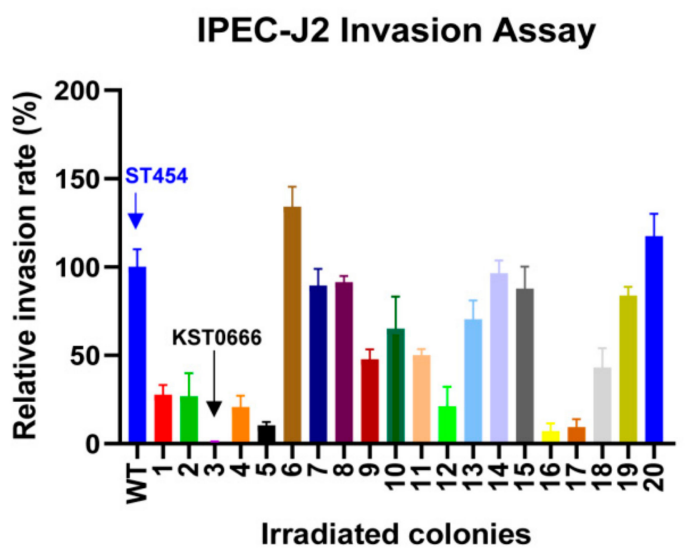

B

\begin{tabular}{ccc}
\hline \multirow{2}{*}{$\begin{array}{c}\text { Infection } \\
\text { number } \\
\text { (CFU) }\end{array}$} & \multicolumn{2}{c}{ Mice survival (\%) } \\
\cline { 2 - 3 } & $\begin{array}{c}\text { WT strain } \\
\text { (ST454) }\end{array}$ & $\begin{array}{c}\text { KST0666 } \\
\text { (\#03 colony) }\end{array}$ \\
\hline $1 \times 10^{4}$ & 100 & 100 \\
$3 \times 10^{4}$ & 25 & 100 \\
$1 \times 10^{5}$ & 0 & 100 \\
$3 \times 10^{5}$ & 0 & 100 \\
$1 \times 10^{6}$ & 25 & 100 \\
$3 \times 10^{6}$ & 0 & 100 \\
$1 \times 10^{7}$ & 0 & 50 \\
$3 \times 10^{7}$ & 0 & 25 \\
$1 \times 10^{8}$ & 0 & 0 \\
$3 \times 10^{8}$ & 0 & 0 \\
\hline
\end{tabular}

Figure 1. Selection of live attenuated Salmonella strain by radiation mutation technology (RMT). (A) The cell invasion ability of Salmonella Typhimurium ST454 WT and its irradiated mutants were tested in the porcine intestinal epithelial cell line IPEC-J2. IPEC-J2 cells were infected with ST454 WT or its irradiated mutants $(n=20)$ at a multiplicity of infection (MOI) of 10 , bacterial viability in cell lysates that were serially diluted was counted at $30 \mathrm{~min}$ post-infection, and invasion rates were calculated as (recovered CFU/original CFU) $\times 100 \%$. (B) The comparison of LD50 values measured in BALB/c mice $(n=4$ per group) injected with either ST454 or KST0666 strain. The survival of infected mice was monitored for 14 days.

Next, $\mathrm{LD}_{50}$ values were measured to determine whether KST0666 was sufficiently attenuated in comparison with WT strain (Figure 1B). The survival rates of mice intraperitoneally injected with WT or KST0666 (ranging from $1 \times 10^{4}$ to $1 \times 10^{8} \mathrm{CFU}$ ) and their survival rates were monitored. All mice infected with the WT strain died within 3 days, whereas the mice infected with lower than $1 \times 10^{7} \mathrm{CFU}$ of KST0666 exhibited 100\% survival for the duration of the study (up to 14 days). Additionally, $50 \%$ and $25 \%$ of mice injected with $1 \times 10^{7}$ and $3 \times 10^{7} \mathrm{CFU}$ of KST0666, respectively, survived, indicating that it was attenuated at least 500 times than its parent strain.

To analyze the location of mutations in KST0666, the complete genome of KST0666 was sequenced and compared to that of the WT strain as reference. As shown in Table 3, there were 16 genetic alterations, including 3 deletions, 1 insertion, and 12 point mutations detected in KST0666.

Table 3. Summary of the mutational spectrum observed in KST0666.

\begin{tabular}{ccccc}
\hline Mutation Type & Deletion & Insertion & Point & Total \\
\hline Silent & 0 & 0 & 4 & 4 \\
Missense & 0 & 0 & 7 & 7 \\
Nonsense & 0 & 0 & 1 & 1 \\
Frameshift & 2 & 1 & 0 & 3 \\
Non-frameshift & 1 & 0 & 0 & 1 \\
Total & 3 & 1 & 12 & 16 \\
\hline
\end{tabular}


Among the 12 point mutations, 4 silent, 1 non-sense, and 7 missense mutations were found that may interfere with the functions of several damage repair or virulence genes relevant to the attenuation (Table 4).

Table 4. Mutated genes in KST0666.

\begin{tabular}{cccc}
\hline Protein ID & Position & Homologous Protein & Mutant Type \\
\hline ST454_00059 & 55692 & Putative protease SohB & inframe deletion \\
\hline ST454-00105 & 108541 & Respiratory nitrate reductase 1 alpha chain & synonymous variant \\
\hline ST454_00266 & 285135 & Chemotaxis protein CheA & synonymous variant \\
\hline ST454-00371 & 395359 & Cobalt-precorrin-7 C(5)-methyltransferase & synonymous variant \\
\hline ST454-00871 & 888709 & Anaerobic dimethyl sulfoxide reductase chain B & missense variant \\
\hline Non-coding region & 1471061 & Hypothetical protein & frameshift variant \\
\hline ST454-02089 & 2175005 & Hypothetical protein & missense variant \\
\hline ST454-02736 & 2873993 & Bifunctional transcriptional activator/DNA repair enzyme AdaA & missense variant \\
\hline ST454-02754 & 2892634 & Lipopolysaccharide export system permease protein LptG & missense variant \\
\hline ST454-02790 & 2937098 & Secretion monitor & missense variant \\
\hline ST454-03046 & 3209927 & Putative lipoprotein ChiQ & missense variant \\
\hline ST454-03672 & 3848803 & & synonymous variant \\
\hline Non-coding region & 4023820 & O-acetyl-ADP-ribose deacetylase & frameshift variant \\
\hline ST454-04101 & 4326390 & Hypothetical protein & nonsense \\
\hline ST454-04336 & 4590924 & Ribulose-phosphate 3- epimerase & missense variant \\
\hline ST454-04577 & 4819484 & frameshift variant \\
\hline
\end{tabular}

Notably, two deletions and one insertion resulted in frameshift mutations through one nucleotide addition or loss. In total, two of them were detected in non-coding regions, and another was present in ST454-WT_04577 (Ribulose-phosphate-3-epimerase). In addition, an inframe deletion was detected in ST454-WT_00059 (putative protease SohB) wherein six nucleotides were missing. Taken together, these random alterations in nucleotides and amino acids might contribute to the attenuation of KST0666.

\subsection{Expression of VP1 in Response to recN Promoter in KST0669}

We previously developed a protein delivery system with a $\operatorname{rec} N$ promoter under regulation of external stresses, such as DNA damage and reactive oxygen species [38]. Considering the immunogenicity of the VP1 capsid protein in FMDV infection, the VP1 protein-expressing system (pRECN-VP1) was constructed as shown in Figure 2A and transferred to KST0666 strain. To determine the safety of KST0666 harboring pRECNVP1 (KST0669), BALB/c mice were orally inoculated with $1 \times 10^{8}$ CFU of KST0669 and the numbers of colonized bacteria in organs were counted at day 1,2, 3, 5, and 7 postinoculation. There were no obvious clinical symptoms or body weight decline during the 7-day observation period post-inoculation. As shown in Figure 2, the invading Salmonella was completely eliminated from the spleen (Figure 2B), mesenteric lymph node (Figure 2C), and liver (Figure 2D) on day 7 post-infection, indicating the safety of this system in the mouse model. 
A

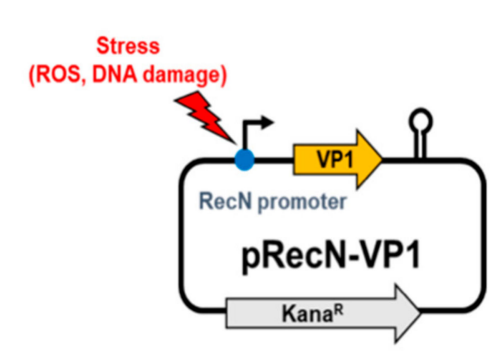

C

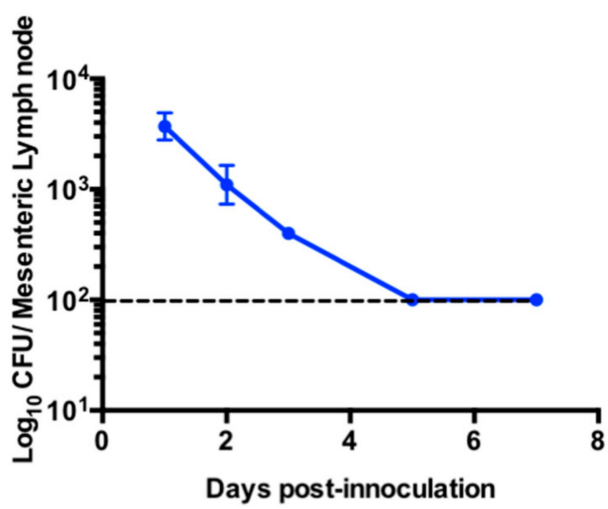

B

D
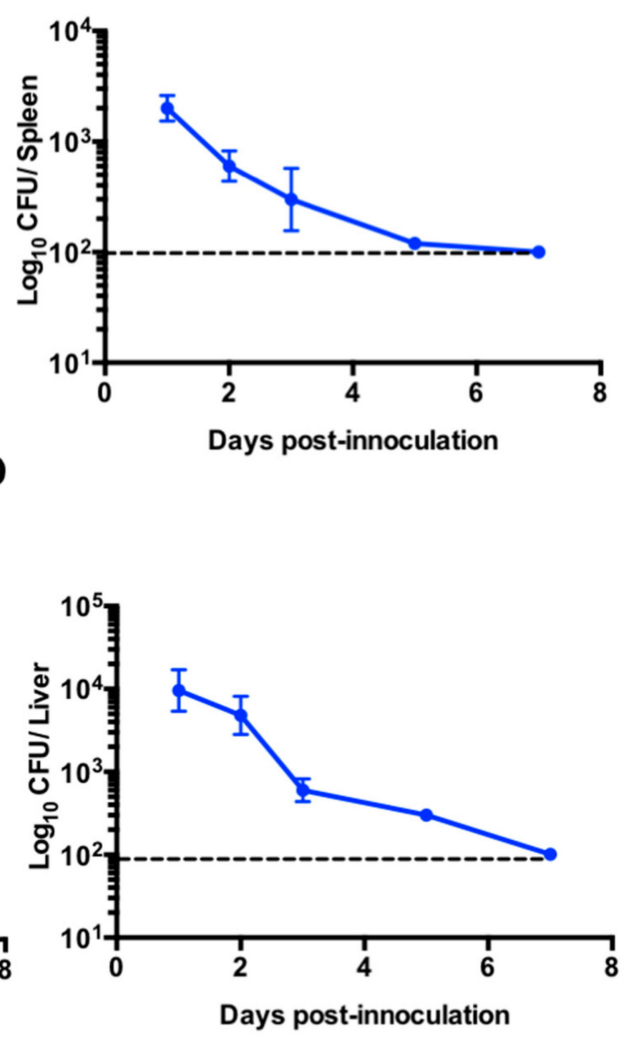

Figure 2. Virulence of Salmonella KST0666, containing pRECN-VP1 (KST0669). (A) Schematic plasmid map of stressinducible VP1-expressing plasmid, pRECN-VP1. (B-D) In Vivo virulence of KST0669. The colonization capacity of KST0669 in mice was measured in the spleen (B), the mesenteric lymph node (C), and the liver (D). BALB/c mice $(n=5$ per group) were orally administrated $1 \times 10^{8} \mathrm{CFU}$ of KST0669, and euthanized on day 1, 2, 3, 5, and 7 post-infection. Bacterial viability was assessed in organ lysates that were serially diluted and plated on LB agar plates. Results are presented as mean \pm SEM per group. The interrupted line indicates the undetectable level of bacteria. ROS, reactive oxygen species.

Subsequently, we examined the expression of VP1 in KST0669. As shown in Figure 3A, the VP1 protein was marginally expressed in bacteria under normal conditions; in contrast, under DNA damaging stress environment (irradiation with UV-B), an increased expression was detected both in the culture supernatant and cytoplasm of the lysed cell pellet.

We further quantified the expression of VP1 in macrophages, i.e., RAW264.7 cells infected with KST0669 (MOI of 10) using RT-qPCR. VP1 expression levels in the infected RAW264.7 cells were $2.65 \pm 0.84$ - and $13.99 \pm 2.01$-times higher than in the PBS control group at 2 and $18 \mathrm{~h}$ post-infection, respectively (Figure 3B). To visualize VP1 expression in RAW264.7 cells, intracellular VP1 expressed by KST0669 was tagged with FITC-conjugated antibody and visualized by confocal microscopy (Figure 3C). At $2 \mathrm{~h}$ post-infection, a strong fluorescent signal was detected inside and outside the KST0669-infected RAW264.7 cells, and the intracellular expression of VP1 further increased at $18 \mathrm{~h}$ post-infection. These data suggested that KST0669 efficiently expressed the VP1 protein in antigen-presenting macrophages. 
A

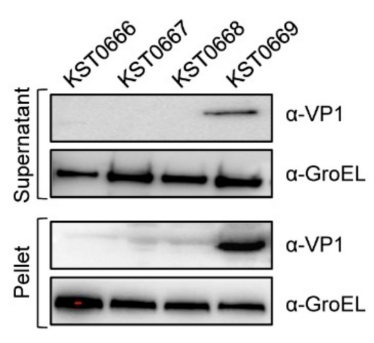

C

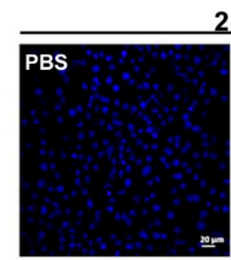

$2 \mathrm{~h}$

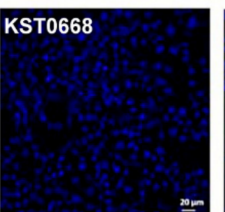

B

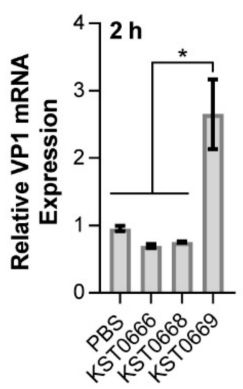

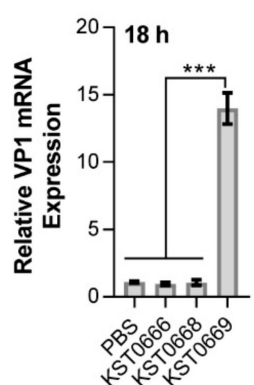

$18 \mathrm{~h}$
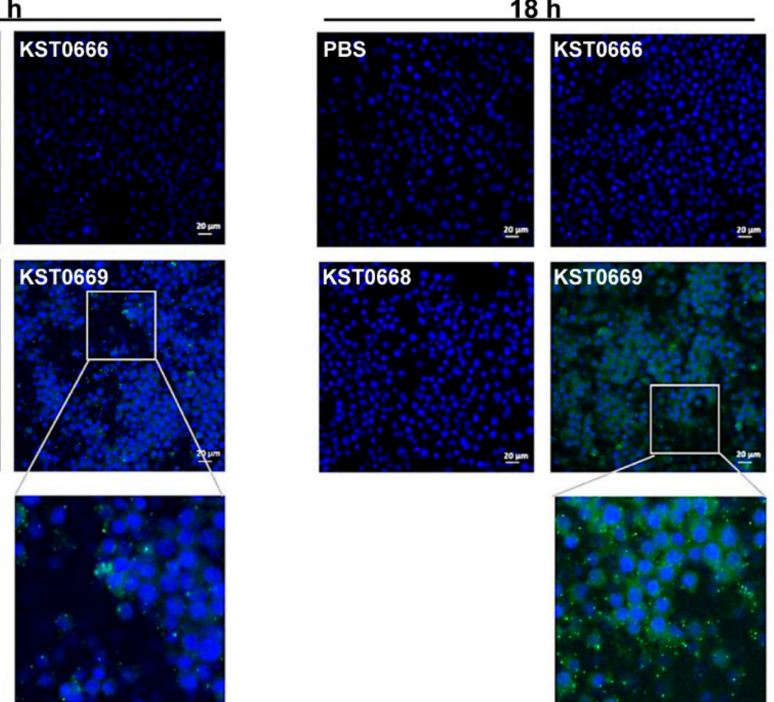

Figure 3. Expression of VP1 protein and mRNA in KST0669. (A) KST0666, KST0667, KST0668, or KST0669 were grown to mid-log phase and proteins were extracted from cell pellets and culture supernatants, after centrifugation. VP1 protein expression levels were measured with a rabbit anti-FMDV antibody and detected by western blotting. $\alpha$-VP1: anti-VP1; $\alpha$-GroEL: anti-GroEL. (B) VP1 mRNA expression levels in Salmonella-infected mouse macrophages. RAW264.7 cells $\left(5 \times 10^{5}\right.$ per well) were infected with KST0666, KST0668, or KST0669 (MOI = 10) and phosphate-buffered saline (PBS)-treated RAW264.7 cells were used as negative control. Total mRNA was isolated at 2 and $18 \mathrm{~h}$ post-infection, and VP1-specific mRNA levels were measured using RT-qPCR. Data are expressed as mean \pm SEM per group and analyzed by $t$ test. ${ }^{* * *} p<0.005,{ }^{*} p<0.05$. (C) Visualization of VP1 protein expression in Salmonella-infected RAW264.7 cells at 2 and $18 \mathrm{~h}$ post-infection. RAW264.7 cells $\left(5 \times 10^{5}\right.$ per well) were infected with KST0666, KST0668, or KST0669 (MOI = 10). Cell nuclei were stained with DAPI (blue), and VP1 protein (green) was detected with rabbit anti-FMDV IgG and FITC-conjugated goat anti-rabbit IgG.

\subsection{Mucosal and Humoral FMDV-Specific Immune Responses Elicited by KST0669 Vaccination}

The primary site of FMDV invasion is the pharyngeal area, suggesting that mucosal immunogenicity plays a critical role in preventing FMDV replication and the damage caused by FMDV [43]. In order to evaluate if oral immunization of live KST0669 was able to elicit FMDV-specific mucosal and humoral immune responses, the fecal and sera samples of immunized mice were collected as shown in Figure 4A. In mice vaccinated with either KST0668 or KST0669, there was no difference in Salmonella lipopolysaccharide (LPS)-specific fecal IgA titers for 4 weeks indicating that the number of vaccinated Salmonella was similar

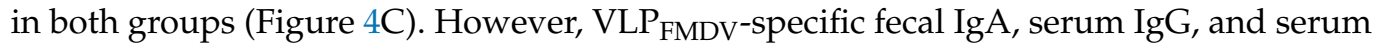
IgM were not detected in the KST0668-vaccinated group, which was comparable with the PBS-injected control group (Figure 4B,D,E). On the contrary, the KST0669-vaccinated group showed significantly increased fecal IgA, serum IgG, and serum IgM titers compared to those in KST0668-vaccinated group in a time-dependent manner. The elevated antibody 
levels in the KST0669-vaccinated group indicated that our delivery system successfully delivered the VP1 antigen to immune cells and effectively induced both mucosal and humoral immunity.

A

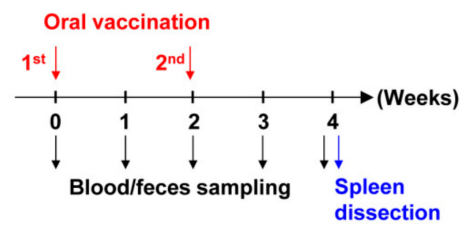

C

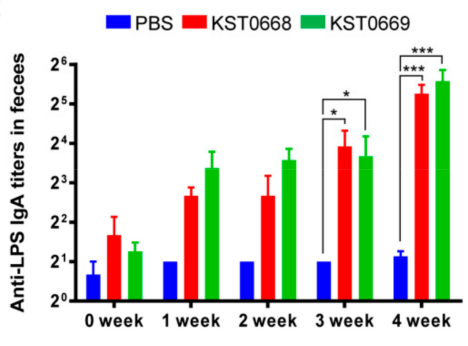

E

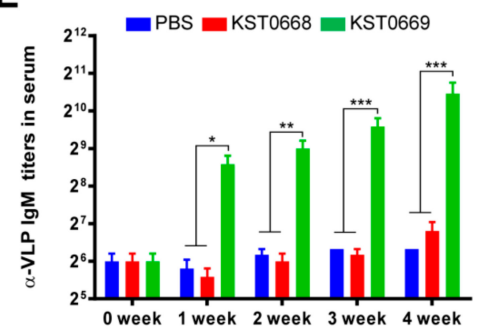

B

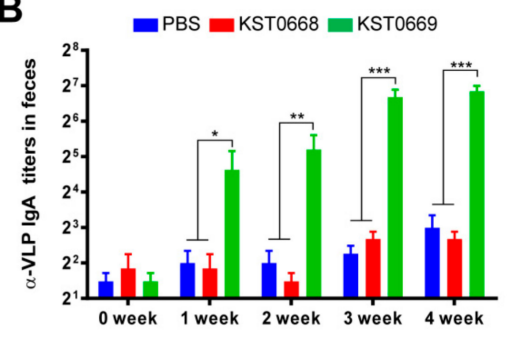

D

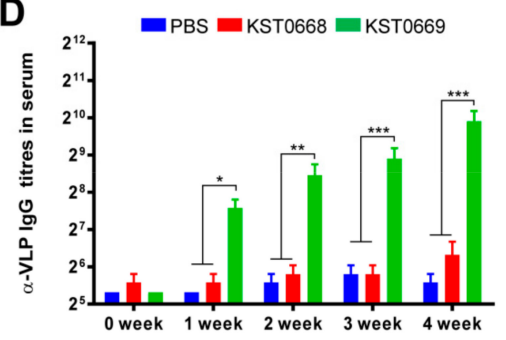

$\mathbf{F}$

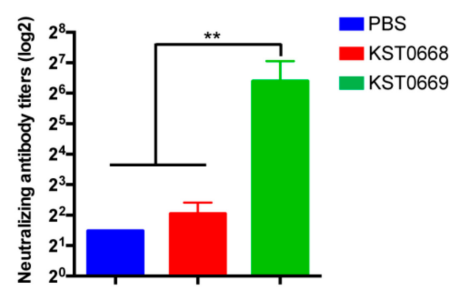

Figure 4. Humoral and mucosal immune responses induced by immunization with KST0669. (A) Schematic of the mouse experiment schedule. Mice ( $n=5$ per group) were orally administrated $1 \times 10^{8}$ CFU KST0668 or KST0669 twice at 2-week

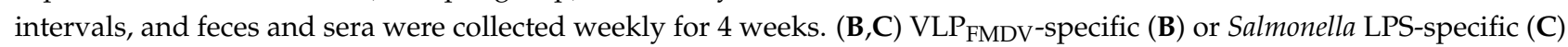
IgA in feces. VLP FMDV $(2 \mu \mathrm{g} / \mathrm{mL})$ and Salmonella LPS $(1 \mu \mathrm{g} / \mathrm{mL})$ were immobilized on 96 -well plate and IgA titer was

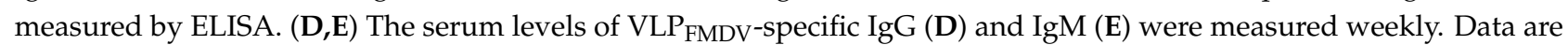
expressed as mean \pm SEM per group and analyzed by two-way ANOVA followed by a post-hoc Tukey test. (F) Neutralizing activity of FMDV in sera from PBS-, KST0668-, and KST0669-vaccinated mice. Pooled sera from immunized mice $(n=5$ per group) at day 14 after the last vaccination were serially diluted and incubated with FMDV followed by incubation with BHK-21 cells. Cytopathic effects of the sera were measured $72 \mathrm{~h}$ after incubation. Data are expressed as mean \pm SEM per group and analyzed by unpaired $t$ test. ${ }^{* * *} p<0.005,{ }^{* *} p<0.01$, and ${ }^{*} p<0.05$. $\alpha$-VLP: anti-VLP.

Next, anti-FMDV neutralizing activity was examined to measure the functional activity of mouse sera from KST0699-vaccinated mice. As shown in Figure 4F, sera from PBS- or KST0668-vaccinated mice had marginal neutralizing antibody titers, whereas sera from KST0669-vaccinated mice had significantly higher levels of neutralizing antibody titers $(87 \pm 16.15)$ than that from KST0668-vaccinated mice. These results indicated that our delivery system effectively delivered VP1 to the immune cells, inducing mucosal, humoral, and functional FMDV-specific immune responses.

\subsection{Higher FMDV-Specific T-Cell Immunity Induced by Oral KST0669 Vaccination}

As $\mathrm{CD}^{+}$and $\mathrm{CD}^{+}{ }^{+}$cells are important for protection against viral infections, including FMDV [24,25], we assessed the activation of cell-mediated immune response in KST0669-vaccinated mice. The single cell suspensions of splenocytes isolated from each orally vaccinated (twice at 2-week intervals) mice were re-stimulated with $10 \mu \mathrm{g}$ 
$\mathrm{VLP}_{\mathrm{FMDV}}$. Then, $\mathrm{VLP}_{\mathrm{FMDV}}$-specific type $1 \mathrm{~T}$ helper (Th1; IFN- $\gamma$-expressing $\mathrm{CD} 4^{+} \mathrm{T}$ cells), Th2 (IL-5-expressing CD4 ${ }^{+} \mathrm{T}$ cells), Th17 (IL-17A-expressing CD4 ${ }^{+} \mathrm{T}$ cells), and activated $\mathrm{CD}^{+} \mathrm{T}$ cells (IFN- $\gamma$-expressing CD8 $8^{+} \mathrm{T}$ cells) were analyzed as described in Figure $5 \mathrm{~A}$. As shown in Figure 5B, significantly increased frequencies of IFN $-\gamma^{+} \mathrm{CD} 4^{+}, \mathrm{IL}-5^{+} \mathrm{CD} 4^{+}$, and IL-17A ${ }^{+} \mathrm{CD}^{+}$cells were detected in KST0669-vaccinated group compared to those in PBSand KST0668-vaccinated groups. Additionally, a significantly increased level of activated $\mathrm{CD}^{+} \mathrm{T}$ cells (IFN- $\gamma^{+} \mathrm{CD} 8^{+} \mathrm{T}$ cells) in the KST0669-vaccinated group was found compared to that in the PBS- and KST0668-vaccinated groups.
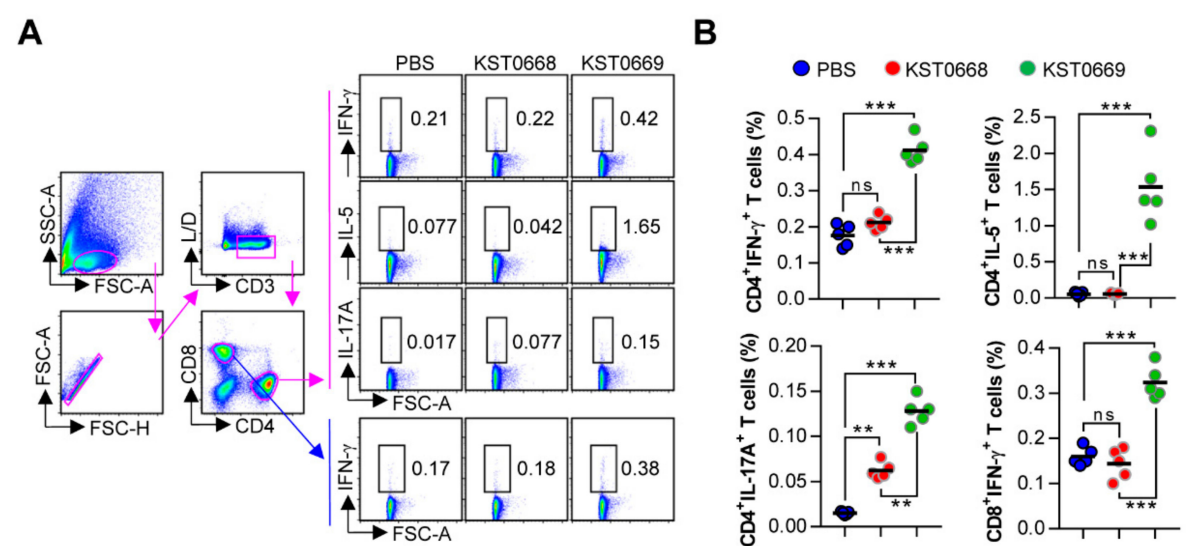

Figure 5. Analysis of $\mathrm{VLP}_{\mathrm{FMDV}}$-specific $\mathrm{CD} 4^{+}$and $\mathrm{CD}^{+} \mathrm{T}$-cell responses. Mice ( $n=5$ per group) were vaccinated orally twice with PBS, KST0668, or KST0669. (A,B) Spleen cell suspensions were re-stimulated with $10 \mu \mathrm{g} / \mathrm{mL}$ VLP FMDV for $12 \mathrm{~h}$ and $\mathrm{VLP}_{\mathrm{FMDV}}$-specific Th1 (IFN- $\gamma$-expressing CD4 ${ }^{+} \mathrm{T}$ cells), Th2 (IL-5-expressing CD4 ${ }^{+} \mathrm{T}$ cells), Th17 (IL-17A-expressing $\mathrm{CD}^{+} \mathrm{T}$ cells), and activated $\mathrm{CD} 8^{+} \mathrm{T}$ cells (IFN- $\gamma$-producing $\mathrm{CD} 8^{+} \mathrm{T}$ cells) were analyzed by intracellular cytokine staining based on the T cell-specific makers (anti-CD3, anti-CD4, and anti-CD8 antibodies). (A) The representative plot for Th1, Th2, Th17, and activated CD8 ${ }^{+}$T cells in spleen of PBS-, KST0668-, and KST0669-vaccinated mice. (B) The percentages of Th1, Th2, Th17, and activated CD8 ${ }^{+} \mathrm{T}$ cells in spleen of all vaccinated mice. The mean $\pm \mathrm{SD}$ shown are representative of two independent experiments. ${ }^{* *} p<0.005,{ }^{* *} p<0.01$, ns $=$ not significant.

$\mathrm{VLP}_{\mathrm{FMDV}}$-specific cytokine levels in splenocytes isolated from each vaccinated group were measured by ELISA (Figure 6). Significantly increased levels of IFN- $\gamma$, IL-5, and IL-17A were detected in the KST0669-vaccinated group compared to those in PBS- or KST0668-vaccinated groups. This confirmed that our delivery system could induce FMDVspecific immune responses in Th1, Th2, and Th17 cells. Since Th17 cells and IL-17 cytokine from the mucosal compartment are reportedly associated with the transmission of bacterial and viral infection $[44,45]$, a dramatic increase in FMDV-specific IL-17 secretion should be relevant in terms of providing protection against FMDV mucosal infections.

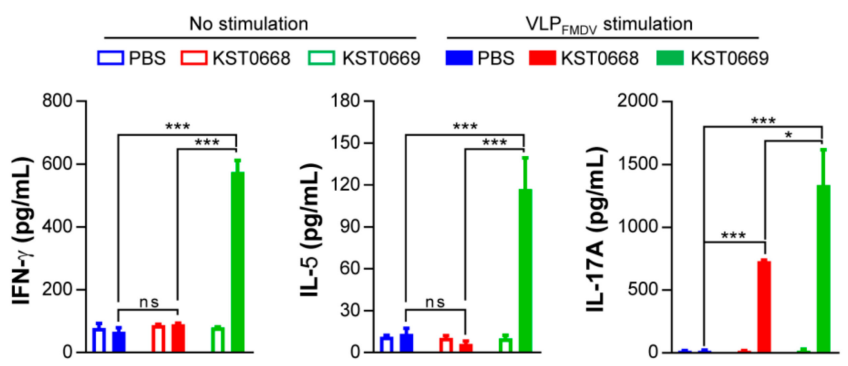

Figure 6. VLP $\mathrm{FMDV}$-specific cytokine production in spleen cells of vaccinated mice. Mice ( $n=5$ per group) were vaccinated orally twice with PBS, KST0668, or KST0669. Single cell suspensions of splenocytes were treated with $10 \mu \mathrm{g} / \mathrm{mL} V_{\text {VLPMV }}$ for $24 \mathrm{~h}$, and supernatants were collected for

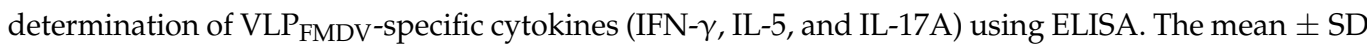
shown are representative of two independent experiments. ${ }^{* *} p<0.005,{ }^{*} p<0.05$, ns $=$ not significant. 


\subsection{Protection Against Salmonella Typhimurium Infection Through KST0669 Vaccination}

To confirm that KST0669 vaccination could protect against not only FMDV but also Salmonella infection, mice were immunized as shown in Figure $4 \mathrm{~A}$ and infected orally with Salmonella Typhimurium LT2 $\left(1 \times 10^{6} \mathrm{CFU}\right)$ for 2 weeks. The survival rates of mice were monitored for 2 weeks after infection. As shown in Figure 7D, all mice in the PBSinjected group died within 7 days after infection, whereas all mice vaccinated with KST0669 survived for 2 weeks. To assess the ratio of Salmonella invasion in mice, the numbers of Salmonella Typhimurium LT2 in the intestine, spleen, and blood was measured at 2, 4, and 6 days post-infection. As shown in Figure 7A,B, the KST0669-vaccinated group showed significantly lower viability of Salmonella Typhimurium LT2 colonization in the cecum and spleen than that in the PBS control group. In addition, Salmonella Typhimurium LT2 invasion in mouse blood increased day-by-day in the PBS group, whereas no bacteria were detected in the blood of the KST0669-vaccinated group (Figure 7C). These data indicate that the KST0669 vaccination effectively prevents lethal Salmonella Typhimurium challenge.

A

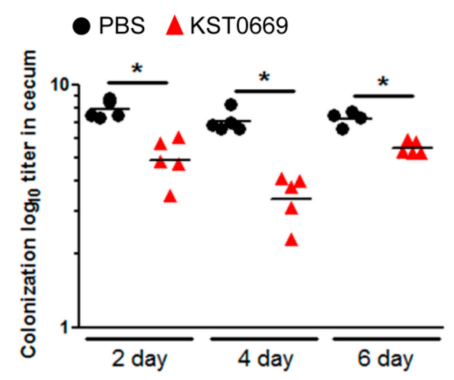

C

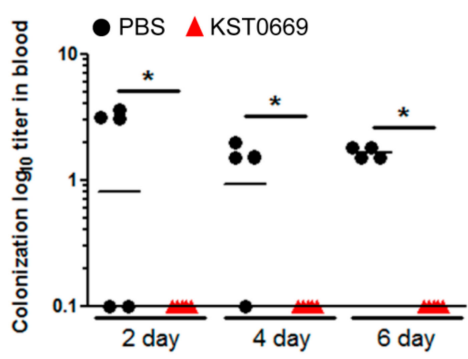

B

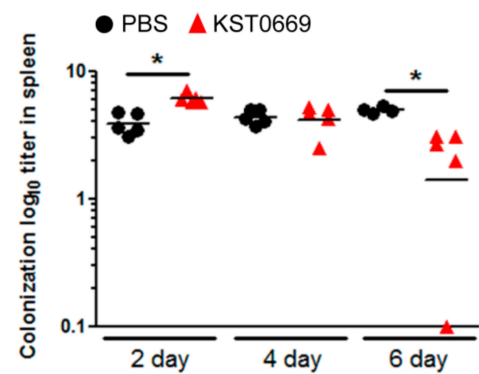

D

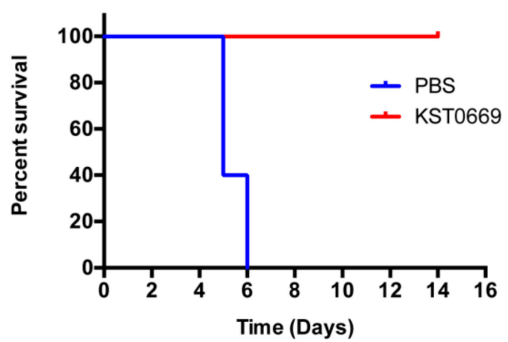

Figure 7. Protection against Salmonella infections. Mice ( $n=5$ per group) were orally immunized with PBS (black circle) or KST0669 (red triangle) twice at two-week intervals and then infected orally with $1 \times 10^{6}$ CFU Salmonella Typhimurium LT2 strain. (A-C) Mice organs (cecum and spleen) and bloods were isolated at 2, 4, or 6 days post-infection. The CFU of bacteria in the cecum (A), the spleen (B), and blood (C) were counted. (D) Mice survival was monitored for 14 days. Data are expressed as mean \pm SEM per group and analyzed by unpaired $t$ test. ${ }^{*} p<0.05$.

\section{Discussion}

Since FMD is one of the most economically devastating veterinary diseases, vaccination is the only effective strategy to prevent its disease burden and spread. Currently, chemically inactivated FMDV vaccine is widely used worldwide, but its protective efficacy has been reported as low as $60 \%$ [46]. Therefore, several next generation vaccines, such as mucosal, VLP, and peptide-based vaccines, have been developed as alternatives that may elicit superior immune responses against FMDV infection. Several studies have reported that the mucosal and T-cell dependent immune responses were induced by using live attenuated bacterial delivery systems, such as Salmonella Typhimurium, Lactococcus lactis, and Bacillus subtilis [47-51]. However, the present study is the first to report RMT as an effective and time-saving approach to develop live attenuated bacteria as an antigen delivery 
vector. Our novel Salmonella vector named KST0666 was highly attenuated both in vitro and in vivo, and could effectively transfer FMDV antigen (VP1 capsid) to the immune cells in mice. In addition, this new system can elicit a protective immune response against FMDV as well as Salmonella itself.

Radiation has been widely used to induce mutations in crop breeding [52,53]. In addition, several studies have reported the use of RMT in microorganisms to enhance the production of bioactive molecules in bacteria, yeast, or fungi [54-56]. For example, the production of bacterial cellulose, which has a variety of applications in medical and industrial field, was highly improved by radiation-induced mutagenesis in Komagataeibacter hansenii and Gluconacetobacter xylinus $[57,58]$. We previously developed attenuated Salmonella by applying RMT to improve its target activity against the tumor microenvironment [38]. Genome analysis of this Salmonella strain revealed that several mutations, including deletions and insertions, that are rarely found in chemical mutagenesis, were induced by RMT. Compared to the parent strain, KST0666, developed by RMT, was mutated at 16 sites with 3 deletions, 1 insertion, and 12 point mutations. Interestingly, a missense mutation was detected in the AdaA gene, which encodes a DNA repair enzyme that plays a role in repairing the adaptive response to alkylation damage [59]. Another missense mutation was found in the LptG gene that is involved in the transport of LPS from inner membrane to the cell surface [60]. The combination of several identified candidate mutant genes can trigger attenuation of KST0666, but the exact mechanism of attenuation remains still unclear. It is also necessary to investigate the mechanism of attenuation due to single or multiple gene mutations through genetic manipulation.

To enhance the cellular immune response of FMDV vaccines, many approaches have been developed. The viral vectors can easily express and deliver immunogenic structural proteins of FMDV to induce diverse immune responses in vector-infected cells [61]. Previously, a human replication-defective adenovirus subunit vaccine (Ad5-O1Man) was genetically modified to express the capsid and capsid-processing proteins of FMDV, and consequently induced neutralizing antibodies in swine [62]. Recently, another Ad5 vaccine coexpressing the VP1 capsid gene with the 3C protease gene of FMDV A12/119/Kent/UK/32 was shown to protect direct contact homologous FMDV transmission in cattle [63]. Live attenuated bacterial strains as a vaccine vector have been widely studied for their advantages in stimulating mucosal and cellular immunity [26]. Lactococcus is generally considered safe and is known to be able to induce adjuvant effects non-specifically through macrophage activation [64]. For example, Lactobacillus plantarum with the pSIP411-VP1 plasmid induces VP1-specific IgG and mucosal secretory IgA, providing protective immunity against FMDV infection in guinea pigs [65]. Our Salmonella system was shown to be similar, in terms of eliciting an immune response, to previously reported bacterial vector systems. However, an additional advantage of our system is that the KST0669 vaccine can elicit an immune response against both infecting organisms FMDV and Salmonella. This is significant as Salmonella is a commonly recognized zoonotic pathogen and may colonize the gut of pigs or cattle, contaminating the carcasses during the slaughter process [66].

Furthermore, this is the first study to use VLPs for evaluating FMDV vaccine efficacy. FMDV-specific humoral and cellular immune responses are conventionally measured using live FMDV or killed FMDV prepared in a laboratory with BSL3 facility. There was no need for a BSL3 facility in the present study because it was possible to evaluate the efficacy of the vaccine using VLPs prepared in E. coli. In addition, this method was more quantitative then using live FMDV, so it was possible to ensure accuracy in vaccine evaluation.

\section{Conclusions}

The present study demonstrated a novel strategy to develop a live attenuated bacterial vector system using RMT. This system effectively delivered the viral antigen to immune cells in vivo to elicit both FMDV- and Salmonella-specific immune responses. In addition, this is the first study to successfully evaluate the $\mathrm{VLP}_{\mathrm{FMDV}}$-specific humoral and cellular immune responses against FMDV. Collectively, our data provide important information for 
developing vector-based FMDV vaccines and evaluating the efficacy of a novel concept of FMDV vaccines in a (BSL1) laboratory.

Author Contributions: Conceptualization, H.S.S.; methodology, Y.Z., H.J.J., H.G. and H.S.S.; formal analysis, Y.Z., H.J.J. and W.S.K.; investigation, Y.Z.; writing—original draft preparation, Y.Z.; writingreview and editing, J.H.L., W.S.K. and H.S.S.; supervision, H.S.S.; project administration, H.S.S. and E.-B.B. All authors have read and agreed to the published version of the manuscript.

Funding: This work was supported by the National Research Foundation of Korea under grants NRF-2019R1C1C1002484 to E.-B.B. and NRF-2020M2D8A3094054 to H.S.S.

Institutional Review Board Statement: All animal experiments for the study were conducted according to accepted veterinary standards set by the Korea Atomic Energy Research Institute (KAERI) animal care center, and approved by the Ethics Committee on the use and care of animals at the KAERI (The approval number is IACUC-2018-007).

Informed Consent Statement: Not applicable.

Data Availability Statement: The data that support the findings of this study are available on request from the corresponding author.

Conflicts of Interest: The authors declare no conflict of interest.

\section{References}

1. Alexandersen, S.; Zhang, Z.; Donaldson, A.I.; Garland, A.J. The pathogenesis and diagnosis of foot-and-mouth disease. J. Comp . Pathol. 2003, 129, 1-36. [CrossRef]

2. Grubman, M.J.; Baxt, B. Foot-and-mouth disease. Clin. Microbiol. Rev. 2004, 17, 465-493. [CrossRef]

3. McLachlan, I.; Marion, G.; McKendrick, I.J.; Porphyre, T.; Handel, I.G.; Bronsvoort, B.M.D. Endemic foot and mouth disease: Pastoral in-herd disease dynamics in sub-saharan africa. Sci. Rep. 2019, 9, 17349. [CrossRef] [PubMed]

4. Naranjo, J.; Cosivi, O. Elimination of foot-and-mouth disease in south america: Lessons and challenges. Philos. Trans. R. Soc. B Biol. Sci. 2013, 368, 20120381. [CrossRef] [PubMed]

5. Grubman, M.J. The 5' end of foot-and-mouth disease virion rna contains a protein covalently linked to the nucleotide pup. Arch. Virol. 1980, 63, 311-315. [CrossRef]

6. Paton, D.J.; Sumption, K.J.; Charleston, B. Options for control of foot-and-mouth disease: Knowledge, capability and policy. Philos. Trans. R. Soc. B Biol. Sci. 2009, 364, 2657-2667. [CrossRef]

7. Parida, S. Vaccination against foot-and-mouth disease virus: Strategies and effectiveness. Expert Rev. Vaccines 2009, 8, 347-365. [CrossRef]

8. Rweyemamu, M.M.; Unehara, O.; Giorgi, W.; Medeiros, R.; Lucca, D.; Baltazar, M. Effect of formaldehyde and binary ethyleneimine (bei) on the integrity of foot and mouth disease virus capsid. Rev. Sci. Tech. 1989, 8, 747-764. [CrossRef]

9. Horsington, J.; Zhang, Z.; Bittner, H.; Hole, K.; Singanallur, N.B.; Alexandersen, S.; Vosloo, W. Early protection in sheep against intratypic heterologous challenge with serotype o foot-and-mouth disease virus using high-potency, emergency vaccine. Vaccine 2015, 33, 422-429. [CrossRef]

10. Doel, T.R. FMD vaccines. Virus Res. 2003, 91, 81-99. [CrossRef]

11. Cao, Y.; Lu, Z.; Liu, Z. Foot-and-mouth disease vaccines: Progress and problems. Expert Rev. Vaccines 2016, 15, 783-789. [CrossRef] [PubMed]

12. Martin, W.B.; Edwards, L.T. A field trial in south africa of an attenuated vaccine against foot-and-mouth disease. Res. Veter. Sci. 1965, 6, 196-201. [CrossRef]

13. Skinner, H.H. Propagation of strains of foot-and-mouth disease virus in unweaned white mice. Proc. R. Soc. Med. 1951, 44, 1041-1044. [CrossRef] [PubMed]

14. Guo, H.C.; Sun, S.Q.; Jin, Y.; Yang, S.L.; Wei, Y.Q.; Sun, D.H.; Yin, S.H.; Ma, J.W.; Liu, Z.X.; Guo, J.H.; et al. Foot-and-mouth disease virus-like particles produced by a sumo fusion protein system in escherichia coli induce potent protective immune responses in guinea pigs, swine and cattle. Vet. Res. 2013, 44, 48. [CrossRef]

15. Lee, C.D.; Yan, Y.P.; Liang, S.M.; Wang, T.F. Production of fmdv virus-like particles by a sumo fusion protein approach in escherichia coli. J. Biomed. Sci. 2009, 16, 69. [CrossRef]

16. Terhuja, M.; Saravanan, P.; Tamilselvan, R.P. Comparative efficacy of virus like particle (vlp) vaccine of foot-and-mouth-disease virus (fmdv) type o adjuvanted with poly i:C or cpg in guinea pigs. Biologicals 2015, 43, 437-443. [CrossRef]

17. Cao, Y.; Lu, Z.; Sun, J.; Bai, X.; Sun, P.; Bao, H.; Chen, Y.; Guo, J.; Li, D.; Liu, X.; et al. Synthesis of empty capsid-like particles of asia $\mathrm{i}$ foot-and-mouth disease virus in insect cells and their immunogenicity in guinea pigs. Veter. Microbiol. 2009, 137, 10-17. [CrossRef] 
18. Bhat, S.A.; Saravanan, P.; Hosamani, M.; Basagoudanavar, S.H.; Sreenivasa, B.P.; Tamilselvan, R.P.; Venkataramanan, R. Novel immunogenic baculovirus expressed virus-like particles of foot-and-mouth disease (fmd) virus protect guinea pigs against challenge. Res. Veter. Sci. 2013, 95, 1217-1223. [CrossRef]

19. Skwarczynski, M.; Toth, I. Peptide-based synthetic vaccines. Chem. Sci. 2016, 42, 854. [CrossRef]

20. Defaus, S.; Forner, M.; Canas-Arranz, R.; de Leon, P.; Bustos, M.J.; Rodriguez-Pulido, M.; Blanco, E.; Sobrino, F.; Andreu, D. Designing functionally versatile, highly immunogenic peptide-based multiepitopic vaccines against foot-and-mouth disease virus. Vaccines 2020, 8, 406. [CrossRef]

21. Mahdy, S.E.; Liu, S.; Su, L.; Zhang, X.; Chen, H.; Pei, X.; Wang, C. Expression of the vp1 protein of fmdv integrated chromosomally with mutant listeria monocytogenes strain induced both humoral and cellular immune responses. Appl. Microbiol. Biotechnol. 2019, 103, 1919-1929. [CrossRef] [PubMed]

22. Zhang, H.Y.; Sun, S.H.; Guo, Y.J.; Zhou, F.J.; Chen, Z.H.; Lin, Y.; Shi, K. Immune response in mice inoculated with plasmid dnas containing multiple-epitopes of foot-and-mouth disease virus. Vaccine 2003, 21, 4704-4707. [CrossRef]

23. Crowther, J.R.; Farias, S.; Carpenter, W.C.; Samuel, A.R. Identification of a fifth neutralizable site on type o foot-and-mouth disease virus following characterization of single and quintuple monoclonal antibody escape mutants. J. Gen. Virol. 1993, 74, 1547-1553. [CrossRef] [PubMed]

24. Carr, B.V.; Lefevre, E.A.; Windsor, M.A.; Inghese, C.; Gubbins, S.; Prentice, H.; Juleff, N.D.; Charleston, B. Cd4+ t-cell responses to foot-and-mouth disease virus in vaccinated cattle. J. Gen. Virol 2013, 94, 97-107. [CrossRef] [PubMed]

25. Guzman, E.; Taylor, G.; Charleston, B.; Ellis, S.A. Induction of a cross-reactive cd8(+) t cell response following foot-and-mouth disease virus vaccination. J. Virol. 2010, 84, 12375-12384. [CrossRef] [PubMed]

26. Lin, I.Y.; Van, T.T.; Smooker, P.M. Live-attenuated bacterial vectors: Tools for vaccine and therapeutic agent delivery. Vaccines 2015, 3, 940-972. [CrossRef]

27. Kotton, C.N.; Hohmann, E.L. Enteric pathogens as vaccine vectors for foreign antigen delivery. Infect. Immun. 2004, $72,5535-5547$. [CrossRef]

28. Xie, Y.; Gao, P.; Li, Z. A recombinant adenovirus expressing p12a and 3c protein of the type o foot-and-mouth disease virus stimulates systemic and mucosal immune responses in mice. BioMed Res. Int. 2016, 2016, 1-9. [CrossRef]

29. Levine, M.M.; Hone, D.; Tacket, C.; Ferreccio, C.; Cryz, S. Clinical and field trials with attenuated salmonella typhi as live oral vaccines and as "carrier" vaccines. Res. Microbiol. 1990, 141, 807-816. [CrossRef]

30. Galen, J.E.; Pasetti, M.F.; Tennant, S.; Ruiz-Olvera, P.; Sztein, M.B.; Levine, M.M. Salmonella enterica serovar typhi live vector vaccines finally come of age. Immunol. Cell Biol. 2009, 87, 400-412. [CrossRef]

31. Shi, H.; Wang, S.; Roland, K.L.; Gunn, B.M.; Curtiss, R., 3rd. Immunogenicity of a live recombinant salmonella enterica serovar typhimurium vaccine expressing pspa in neonates and infant mice born from naive and immunized mothers. Clin. Vaccine Immunol. CVI 2010, 17, 363-371. [CrossRef] [PubMed]

32. Frey, S.E.; Lottenbach, K.R.; Hill, H.; Blevins, T.P.; Yu, Y.; Zhang, Y.; Brenneman, K.E.; Kelly-Aehle, S.M.; McDonald, C.; Jansen, A.; et al. A phase I, dose-escalation trial in adults of three recombinant attenuated salmonella typhi vaccine vectors producing streptococcus pneumoniae surface protein antigen PspA. Vaccine 2013, 31, 4874-4880. [CrossRef] [PubMed]

33. Stevens, M.P.; Humphrey, T.J.; Maskell, D.J. Molecular insights into farm animal and zoonotic salmonella infections. Philos. Trans. R. Soc. B Biol. Sci. 2009, 364, 2709-2723. [CrossRef]

34. Rao, S.; Linke, L.; Doster, E.; Hyatt, D.; Burgess, B.A.; Magnuson, R.; Pabilonia, K.L.; Morley, P.S. Genomic diversity of class i integrons from antimicrobial resistant strains of salmonella typhimurium isolated from livestock, poultry and humans. PLoS ONE 2020, 15, e0243477. [CrossRef] [PubMed]

35. Wilson, C.N.; Pulford, C.V.; Akoko, J.; Perez Sepulveda, B.; Predeus, A.V.; Bevington, J.; Duncan, P.; Hall, N.; Wigley, P.; Feasey, N.; et al. Salmonella identified in pigs in kenya and malawi reveals the potential for zoonotic transmission in emerging pork markets. PLoS Neglected Trop. Dis. 2020, 14, e0008796. [CrossRef] [PubMed]

36. Clark-Curtiss, J.E.; Curtiss, R., 3rd. Salmonella vaccines: Conduits for protective antigens. J. Immunol. 2018, 200, 39-48. [CrossRef] [PubMed]

37. Chin'ombe, N. Recombinant salmonella enterica serovar typhimurium as a vaccine vector for hiv-1 gag. Viruses 2013, 5, 2062-2078. [CrossRef]

38. Gao, S.; Jung, J.H.; Lin, S.M.; Jang, A.Y.; Zhi, Y.; Bum Ahn, K.; Ji, H.J.; Hyang Lim, J.; Guo, H.; Choy, H.E.; et al. Development of oxytolerant salmonella typhimurium using radiation mutation technology (RMT) for cancer therapy. Sci. Rep. 2020, 10, 1-12. [CrossRef]

39. McClelland, M.; Sanderson, K.E.; Spieth, J.; Clifton, S.W.; Latreille, P.; Courtney, L.; Porwollik, S.; Ali, J.; Dante, M.; Du, F.; et al. Complete genome sequence of salmonella enterica serovar typhimurium 1t2. Nature 2001, 413, 852-856. [CrossRef]

40. Livak, K.J.; Schmittgen, T.D. Analysis of relative gene expression data using real-time quantitative pcr and the 2(-delta delta c(t)) method. Methods 2001, 25, 402-408. [CrossRef]

41. McCullough, K.C.; Crowther, J.R.; Butcher, R.N.; Carpenter, W.C.; Brocchi, E.; Capucci, L.; De Simone, F. Immune protection against foot-and-mouth disease virus studied using virus-neutralizing and non-neutralizing concentrations of monoclonal antibodies. Immunology 1986, 58, 421-428. [PubMed]

42. Finney, D.J. Statistical Method in Biological Assay, 2nd ed.; Hafner Pub. Co.: New York, NY, USA, $1964 ;$ p. 668. 
43. Parida, S.; Anderson, J.; Cox, S.J.; Barnett, P.V.; Paton, D.J. Secretory iga as an indicator of oro-pharyngeal foot-and-mouth disease virus replication and as a tool for post vaccination surveillance. Vaccine 2006, 24, 1107-1116. [CrossRef] [PubMed]

44. Jin, W.; Dong, C. Il-17 cytokines in immunity and inflammation. Emerg. Microbes Infect. 2013, 2, 1-5. [CrossRef] [PubMed]

45. Babb, R.; Chen, A.; Hirst, T.R.; Kara, E.E.; McColl, S.R.; Ogunniyi, A.D.; Paton, J.C.; Alsharifi, M. Intranasal vaccination with gamma-irradiated streptococcus pneumoniae whole-cell vaccine provides serotype-independent protection mediated by b-cells and innate il-17 responses. Clin. Sci. 2016, 130, 697-710. [CrossRef] [PubMed]

46. Rodriguez, L.L.; Gay, C.G. Development of vaccines toward the global control and eradication of foot-and-mouth disease. Expert Rev. Vaccines 2011, 10, 377-387. [CrossRef] [PubMed]

47. Kong, W. Development of antiviral vaccine utilizing self-destructing salmonella for antigen and DNA vaccine delivery. Methods Mol. Biol. 2021, 2225, 39-61.

48. Li, Q.; Lv, Y.; Li, Y.A.; Du, Y.; Guo, W.; Chu, D.; Wang, X.; Wang, S.; Shi, H. Live attenuated salmonella enterica serovar choleraesuis vector delivering a conserved surface protein enolase induces high and broad protection against streptococcus suis serotypes 2,7 , and 9 in mice. Vaccine 2020, 38, 6904-6913. [CrossRef]

49. Shirdast, H.; Ebrahimzadeh, F.; Taromchi, A.H.; Mortazavi, Y.; Esmaeilzadeh, A.; Sekhavati, M.H.; Nedaei, K.; Mirabzadeh, E. Recombinant lactococcus lactis displaying omp31 antigen of brucella melitensis can induce an immunogenic response in balb/c mice. Probiotics Antimicrob. Proteins 2020, 1-10. [CrossRef]

50. Song, J.; Zhao, L.; Song, M. A lactococcus lactis-vectored oral vaccine induces protective immunity of mice against enterotoxigenic escherichia coli lethal challenge. Immunol. Lett. 2020, 225, 57-63. [CrossRef]

51. Lv, P.; Song, Y.; Liu, C.; Yu, L.; Shang, Y.; Tang, H.; Sun, S.; Wang, F. Application of bacillus subtilis as a live vaccine vector: A review. J. Vet. Med. Sci. Jpn. Soc. Vet. Sci. 2020, 82, 1693-1699. [CrossRef]

52. Food and Agriculture Organization of the United Nations; International Atomic Energy Agency. The Use of Induced Mutations in Plant Breeding-Report, 1st ed.; Symposium Publications Division: Oxford, NY, USA, 1965; p. 832.

53. Furbank, R.T.; Jimenez-Berni, J.A.; George-Jaeggli, B.; Potgieter, A.B.; Deery, D.M. Field crop phenomics: Enabling breeding for radiation use efficiency and biomass in cereal crops. N. Phytol. 2019, 223, 1714-1727. [CrossRef] [PubMed]

54. Choi, J.I.; Yoon, M.; Joe, M.; Park, H.; Lee, S.G.; Han, S.J.; Lee, P.C. Development of microalga scenedesmus dimorphus mutant with higher lipid content by radiation breeding. Bioprocess Biosyst. Eng. 2014, 37, 2437-2444. [CrossRef] [PubMed]

55. Awan, M.S.; Tabbasam, N.; Ayub, N.; Babar, M.E.; Mehboob ur, R.; Rana, S.M.; Rajoka, M.I. Gamma radiation induced mutagenesis in aspergillus niger to enhance its microbial fermentation activity for industrial enzyme production. Mol. Biol. Rep. 2011, 38, 1367-1374. [CrossRef] [PubMed]

56. Brito, P.P.; Azevedo, H.; Cipolli, K.M.; Fukuma, H.T.; Mourao, G.B.; Roque, C.V.; Miya, N.T.; Pereira, J.L. Effect of the gamma radiation dose rate on psychrotrophic bacteria, thiobarbituric acid reactive substances, and sensory characteristics of mechanically deboned chicken meat. J. Food Sci. 2011, 76, S133-S138. [CrossRef] [PubMed]

57. Li, Y.; Tian, J.; Tian, H.; Chen, X.; Ping, W.; Tian, C.; Lei, H. Mutation-based selection and analysis of komagataeibacter hansenii hdm1-3 for improvement in bacterial cellulose production. J. Appl. Microbiol. 2016, 121, 1323-1334. [CrossRef]

58. Hungund, B.S.; Gupta, S.G. Strain improvement of gluconacetobacter xylinus ncim 2526 for bacterial cellulose production. Afr. J. Biotechnol. 2010, 9, 5170-5172.

59. Sedgwick, B.; Lindahl, T. Recent progress on the ada response for inducible repair of DNA alkylation damage. Oncogene 2002, 21, 8886-8894. [CrossRef]

60. Ruiz, N.; Gronenberg, L.S.; Kahne, D.; Silhavy, T.J. Identification of two inner-membrane proteins required for the transport of lipopolysaccharide to the outer membrane of escherichia coli. Proc. Nat. Acad. Sci. USA 2008, 105, 5537-5542. [CrossRef]

61. Ziraldo, M.; Bidart, J.E.; Prato, C.A.; Tribulatti, M.V.; Zamorano, P.; Mattion, N.; D'Antuono, A.L. Optimized adenoviral vector that enhances the assembly of fmdv o1 virus-like particles in situ increases its potential as vaccine for serotype o viruses. Front. Microbiol. 2020, 11, 591019. [CrossRef]

62. Fernandez-Sainz, I.; Medina, G.N.; Ramirez-Medina, E.; Koster, M.J.; Grubman, M.J.; de Los Santos, T. Adenovirus-vectored foot-and-mouth disease vaccine confers early and full protection against fmdv o1 manisa in swine. Virology 2017, 502, 123-132. [CrossRef]

63. Neilan, J.G.; Schutta, C.; Barrera, J.; Pisano, M.; Zsak, L.; Hartwig, E.; Rasmussen, M.V.; Kamicker, B.J.; Ettyreddy, D.; Brough, D.E.; et al. Efficacy of an adenovirus-vectored foot-and-mouth disease virus serotype a subunit vaccine in cattle using a direct contact transmission model. BMC Veter. Res. 2018, 14, 254. [CrossRef] [PubMed]

64. Liu, J.; Yang, G.; Gao, X.; Zhang, Z.; Liu, Y.; Liu, Q.; Chatel, J.M.; Jiang, Y.; Wang, C. Recombinant invasive lactobacillus plantarum expressing fibronectin binding protein a induce specific humoral immune response by stimulating differentiation of dendritic cells. Benef. Microbes 2019, 10, 589-604. [CrossRef] [PubMed]

65. Wang, M.; Pan, L.; Zhou, P.; Lv, J.; Zhang, Z.; Wang, Y.; Zhang, Y. Protection against foot-and-mouth disease virus in guinea pigs via oral administration of recombinant lactobacillus plantarum expressing vp1. PLoS ONE 2015, 10, e0143750. [CrossRef] [PubMed]

66. Biasino, W.; De Zutter, L.; Mattheus, W.; Bertrand, S.; Uyttendaele, M.; Van Damme, I. Correlation between slaughter practices and the distribution of salmonella and hygiene indicator bacteria on pig carcasses during slaughter. Food Microbiol. 2018, 70, 192-199. [CrossRef] 